\title{
Review: minor analgesics are effective for primary dysmenorrhoea
}

\author{
Zhang WY,Li Wan Po A. Efficacy of minor analgesics in primary dysmenorrhoea: a systematic review. Br J Obstet Gynaecol 1998 \\ Jul;105:780-9.
}

\section{Question}

What is the efficacy and safety of naproxen, ibuprofen, mefenamic acid, and aspirin for primary dysmenorrhoea (painful periods)?

\section{Data sources}

Studies from 1966 to March 1997 were identified by searching Medline, Embase/Excerpta Medica, and Science Citation Index using search terms including dysmenorrhoea, naproxen, ibuprofen, mefenamic acid, aspirin (acetylsalicyclic acid), and paracetamol (acetaminophen); reviewing bibliographies of relevant articles; and communicating with manufacturers.

\section{Study selection}

Published English language studies were selected if they were randomised controlled trials of naproxen, ibuprofen, mefenamic acid, aspirin, or paracetamol for dysmenorrhoea treatment.

\section{Data extraction}

Data were extracted on study design, type of dysmenorrhoea, treatment type and dosage regimen, patient characteristics, pain relief, need for rescue analgesics, restrictions in daily life, absenteeism from work or school, and side effects.

\section{Main results}

56 studies met the inclusion criteria. Naproxen and ibuprofen increased pain relief and decreased use of rescue analgesics and restrictions in daily life compared with placebo (table); naproxen also reduced work or school absences. Aspirin increased pain relief, but did not affect use of rescue analgesics or daily life restrictions; mefenamic acid increased pain relief (table). Naproxen was the only drug that had more side effects than placebo $(p \leq 0.05)$. Direct comparisons of drugs showed that naproxen was better for pain relief than mefenamic acid or aspirin; ibuprofen was better than aspirin.

\section{Conclusions}

Naproxen, ibuprofen, mefenamic acid, and aspirin provide at least moderate pain relief for primary dysmenorrhoea. Naproxen and ibuprofen reduce the need for rescue analgesics and reduce restrictions in daily living. Naproxen reduces work or school absences.

Various analgesics $v$ placebo for dysmenorrhoea*

\begin{tabular}{|c|c|c|c|c|}
\hline \multirow{2}{*}{$\begin{array}{l}\text { Analgesic } \\
\text { (number of trials) }\end{array}$} & \multicolumn{2}{|c|}{ Weighted event rates } & \multirow[b]{2}{*}{$R B I(95 \% C I)$} & \multirow[b]{2}{*}{ NNT $(95 \% C I)$} \\
\hline & Analgesic & Placebo & & \\
\hline \multicolumn{5}{|l|}{ Outcome: pain relief } \\
\hline Naproxen (13) & $59 \%$ & $17 \%$ & $217 \%(172$ to 265$)$ & 3 (2 to 4$)$ \\
\hline Ibuprofen (9) & $70 \%$ & $31 \%$ & $141 \%(58$ to 268$)$ & $3(2$ to 4$)$ \\
\hline Mefenamic acid (3) & $64 \%$ & $31 \%$ & $103 \%$ (65 to 148$)$ & $3(2$ to 5$)$ \\
\hline Aspirin (5) & $29 \%$ & $18 \%$ & $60 \%(12$ to 129$)$ & $10(6$ to 50$)$ \\
\hline \multirow{2}{*}{$\begin{array}{l}\text { Analgesic } \\
\text { (number of trials) }\end{array}$} & \multicolumn{2}{|c|}{ Weighted event rates } & & \\
\hline & Analgesic & Placebo & $R R R(95 \% C I)$ & $N N T(95 \% C I)$ \\
\hline \multicolumn{5}{|c|}{ Outcome: use of rescue analgesics } \\
\hline Naproxen (10) & $18 \%$ & $51 \%$ & $62 \%$ (56 to 68$)$ & $4(3$ to 5$)$ \\
\hline Ibuprofen (2) & $13 \%$ & $57 \%$ & $77 \%(59$ to 87$)$ & $3(2$ to 4$)$ \\
\hline Aspirin (3) & $39 \%$ & $70 \%$ & $21 \%(-8$ to 42$)$ & Not significant \\
\hline \multirow{2}{*}{$\begin{array}{l}\text { Analgesic } \\
\text { (number of trials) }\end{array}$} & \multicolumn{2}{|c|}{ Weighted event rates } & & \\
\hline & Analgesic & Placebo & $R R R(95 \% C I)$ & NNT $(95 \% C I)$ \\
\hline \multicolumn{5}{|c|}{ Outcome: restrictions in daily life } \\
\hline Naproxen (7) & $60 \%$ & $86 \%$ & $29 \%(15$ to 40$)$ & $5(3$ to 8$)$ \\
\hline Ibuprofen (3) & $12 \%$ & $55 \%$ & $74 \%$ (58 to 84$)$ & $3(2$ to 5$)$ \\
\hline Aspirin (3) & $50 \%$ & $62 \%$ & $18 \%(-4$ to 36$)$ & Not significant \\
\hline
\end{tabular}

* Abbreviations defined in glossary. Data provided by author.

Sources of funding: no external funding.

For correspondence: Prof A Li Wan Po, Centre for Evidence-Based Pharmacotherapy, School of Life and Health Sciences, Astom University, Astom Triangle, Birmingham B4 7ET, UK. Fax +44 (0)121 3594693.

\section{Commentary}

Dysmenorrhoea affects $50 \%$ of menstruating women. ${ }^{1}$ This meta-analysis by Zhang and Li Wan Po provides a safety and efficacy profile of commonly used analgesics in the treatment of primary dysmenorrhoea. Ibuprofen, which is increasingly available in over the counter formulations, had the most favourable efficacy to side effect profile. As shown in the table, $70 \%$ of women taking ibuprofen had pain relief compared with 31\% taking placebo (a relative benefit increase of $141 \%$ ). This means that 3 women with dysmenorrhoea would need to be treated with ibuprofen to achieve pain relief in 1 additional woman. Similarly, ibuprofen reduced the need for rescue analgesics by $77 \%$. Weaknesses of this meta-analysis are the exclusion of unpublished research and studies published in languages other than English.

5-20\% of women experience dysmenorrhoea of incapacitating severity. ${ }^{2}$ Research indicates that $<33 \%$ of women with dysmenorrhoea seek treatment from a physician. ${ }^{3}$ Therefore, nurses in community based settings have a unique opportunity to educate women on the findings of this study, particularly the effectiveness of ibuprofen for pain relief with minimal side effects. This study is relevant to occupational health nurses because of their focus on increasing work performance and attendance and to health nurses in schools, where dysmenorrhoea may affect school attendance. For women's health practitioners, the results emphasise the effectiveness of a familiar and relatively inexpensive non-steroidal anti-inflammatory drug in the first line management of primary dysmenorrhoea.

$$
\begin{array}{r}
\text { Tammy Anderer, CRNP, MSN } \\
\text { Family Nurse Practitioner } \\
\text { and Nursing Faculty } \\
\text { The Penn State Geisinger Health System } \\
\text { and Lycoming College } \\
\text { Williamsport, Pennsylvania, USA }
\end{array}
$$

1 Andersch B, Milsom I. Am J Obstet Gynecol 1982;144:655-60.

2 Moulton A, Carlson E. Approach to the patient with pelvic pain. In: Goroll AH, May LA, Mulley AG, editors. Primary care medicine: office evaluation and management of the adult patient. 1995:615-6. 1995:615-6. Hewison A, van den Akker OB.Br J Nurs 1996;
5:480-4. 